\title{
Effective Clusters as Territorial Performance Engines in a Regional Development Strategy - A Triple-Layer DEA Assessment of the Aviation Valley in Poland
}

\author{
Karima Kourtit ${ }^{1}$, Peter Nijkamp ${ }^{2}$, Soushi Suzuki ${ }^{3}$ \\ ${ }^{1}$ KTH Royal Institute of Technology, Stockholm, Sweden; Adam Mickiewicz University, Poznan, Poland \\ (email: karima.kourtit@abe.kth.se) \\ ${ }^{2}$ KTH Royal Institute of Technology, Stockholm, Sweden; Tinbergen Institute, Amsterdam, The Nether- \\ lands; Adam Mickiewicz University, Poznan, Poland (email: pnijkamp1@gmail.com) \\ ${ }^{3}$ Hokkai-Gakuen University, Sapporo, Japan (email: soushi-s@lst.hokkai-s-u.ac.jp)
}

Received: 29 September 2016/Accepted: 18 May 2017

\begin{abstract}
In the past decades, a new concept has been introduced in the regional development literature, viz. economic-technological clusters. A wealth of studies has been published on the conceptual, operational and policy foundation, and relevance of this concept, especially in relation to previously developed regional growth concepts, such as industrial districts, industrial complexes, or growth centers. In the present paper, clusters will be regarded as the spatial foci of sustainable territorial performance strategies and synergetic actions by both public and private actors. This paper aims to address the relevance of cluster concepts for an effective regional development policy, based on the notion of territorial capital. It does so by introducing a new concept, viz. effective cluster, in which spatial-economic synergy, local/regional concentration of industry, and the supporting role of territorial capital are regarded as the main determinants of a highly performing cluster in a given territory. The effective cluster concept will be illustrated and tested on the basis of a field study on the aviation and aerospace cluster 'Dolina Lotnicza' in the Podkarpackie region in South-East Poland. This is one of the most vibrant high-tech clusters in the country. Rather than providing a critical assessment of the specific development strategy of the Podkarpackie region, this study will show the added value of a new general conceptual framework based on effective clusters. A novel approach based on a triple-layer architecture will be adopted here, viz. a quantitative comparative analysis of the 16 Polish 'voivodships' (main administrative regions in the country, at a NUTS-2 level), a benchmark analysis of the 25 counties ('powiats') within the Podkarpackie voivodship (at a NUTS-4 level), and an effective industrial cluster analysis on the basis of the individual aviation firms located in the Podkarpackie region. In each step, an extended Data Envelopment Analysis (DEA), characterized by a merger of a Slack-Based Measure (SMB) and a super-efficiency (SE) DEA model, will be used in order to achieve an unambiguous ranking of the various regions or relevant Decision Making Units (DMUs) in the area concerned. The study will employ an extensive database based on field work among the individual actors in the cluster, in combination with a broadly composed territorial-capital database for the areas under study. The paper will be concluded with some strategic policy lessons.
\end{abstract}




\section{Introduction: Aviation as a Smart Specialization}

Over the past decades, regional development policy has sought to remove the deficiencies in the economic structure of less developed regions through the development of effective infrastructures and the use of appropriate knowledge and innovation systems. Clearly, modern regional development policy seeks to exploit often the economic potential of promising - though not necessary lagging - regions through the creation of accessible transport and communication systems and the transmission of advanced knowledge among actors (see Acz et al. 2009). An important intervening opportunity for an effective use and dissemination of knowledge among actors is formed by social capital (see Westlund 2006). Against this background, regions in an advanced knowledge economy and an open systems' network may act as an economic and technological engine for accelerated knowledge-based spatial development.

Nowadays, there is an increasing awareness that regions should exploit their competitive advantage through a focus on those cognitive activities in which the regions concerned have a proven excellence. This has prompted the notion of smart specialization. The rationale of this concept is based on the idea that in an open world, regions and industries have to compete for the most efficient market strategy, so as to maximize their revenues through a specialization in the most productive or efficient activities. Consequently, regional clusters of industries should not engage in a broad and unfocussed portfolio of industrial or service activities, but should rather seek to optimize their market position on the basis of a smart choice of a limited number of specialized industries (see Batabyal, Nijkamp 2015), such as medical technology, nanotechnology, or environmental technology.

A good example of regional smart specialization is formed by the airline industry. Aviation is a rapidly growing industry world-wide. For example, it is sometimes argued that in the decades to come at least 30,000 new aircraft would have to be built so as to meet the rising demand of mobile people. In the light of this large-scale global development, this dynamic offers, of course, a great opportunity for regional development, provided a proper aviation specialization is strived for from a place-based perspective.

Central and Eastern Europe has a long-standing tradition in the development of aircraft and related products, in particular the Czech Republic, Romania, and Poland. After the fall of the iron curtain, these countries have aimed to employ the historical roots of their former strong aviation industry as an anchor point for developing new regional spearheads in the aerospace industry (see for a review Bochniarz 2007). One of the regions which has in recent years played an active role in the redevelopment of a modern aviation sector is the Podkarpackie region in the South-Eastern part of Poland. It has heavily invested in new infrastructures, advanced knowledge, and international linkages so as to build up a modern aerospace industry. To emphasize the smart aviation specialization in this region, it has in recent years been baptized as the Aviation Valley (see Kaszuba 2012).

The smart specialization in aerospace activities in a given region is based on the assumption that this knowledge-intensive and innovation-driven activity may form a cornerstone for new advanced activities in the area concerned. This modern cluster specialization may generate high revenues, many new jobs, and a high international profile. This calls of course for a thorough (mainly quantitative) assessment of all relevant effects of such an aviation cluster. A good example of such an impact study, on the Boeing aviation cluster in Washington State (USA), can be found in CAI (2013) and Sommers et al. (2008). Additionally, in recent years, various studies in Europe have been carried out on the (regional-) economic significance of the aviation sector. Some interesting examples can be found in a study for the European Commission (ECORYS 2009), and in a study on aviation networks (Zuliani, Jalebert 2005). A policy-oriented study on the regional aerospace cluster policy in Europe can be found in Schönfeld, Jouaillec (2008).

It goes without saying that in the light of the economic and cognitive importance of high-quality regional aviation initiatives, proper decisions have to be taken on the choice of the portfolio of activities, on the skill levels needed, on the necessary infrastructural provisions, and on the set of innovation strategies needed to ensure the highest performance of the cluster concerned. 
In the light of the previous observations, this paper aims to assess the success factors of the Polish Aviation Valley by seeking to arrive at a relative performance ranking of key actors, by using a 3-stage Data Envelopment Analysis (DEA), for an effective cluster constellation to be evaluated in three successive steps: (i) a comparative evaluation of the performance of the Podkarpackie region in South-East Poland vis-à-vis the other main administrative regions ('voivodships'); (ii) a comparative evaluation of the performance of the 25 counties ('powiats') in the Podkarpackie region that are the home base of the various firms in the Aviation Valley in Podkarpackie; and (iii) a comparative evaluation of the micro performance of the most important aviation business firms in this cluster on the basis of detailed interview information from these firms. The methodological toolbox for this triple-layer assessment comprises in particular: principal component analysis (PCA) and Data Envelopment Analysis (DEA).

The present study is organized as follows. After this introductory section, Sections 2 and 3 will, respectively, be devoted to a conceptual exploration and a concise description of the economic backgrounds and the current cluster position of the above mentioned Aviation Valley in Poland. In Section 4, we will present the methodological backgrounds of our territorial performance model, followed by a description of the database collected and employed for our research purposes. In Section 5, the operational model will be treated in the form of a comparative benchmark analysis of the constituents of the triple-layer architecture, where territorial capital data will be used as input for the DEA. The subsequent section (Section 6) will be devoted to a description and interpretation of our results, while the final section will offer concluding remarks, in particular on policy lessons for the Aviation Valley.

\section{Territories and Production Units in Clusters}

Regional development is not 'manna from heaven', but the result of deliberate smart strategic choices, decisions, and actions of stakeholders in a given area. It is based on an effective policy effort - both public and private - to shape attractive conditions for accelerated sustainable growth in a geographically concentrated area (see Andersson et al. 2016). The achievement of such a goal needs the fulfilment of various prerequisites: economies of density of activities, multi-tasking synergy of smart development strategies, and existence and exploitation of internal and external network liaisons among all relevant actors (see for an overview Capello, Nijkamp 2009).

In the rich history of regional development policy a variety of instrumental concepts has come to the fore: industrial districts, growth poles, growth centers, geographical clusters, development axes, industrial complexes, special economic zones, high-tech parks, etc. Despite a diversity in meaning and scope of such spatial growth concepts, they all served to enhance the economic performance of the area concerned, with a view to formulating and implementing solid strategies in order to improve its socio-economic competitive profile and to reduce spatial disparities in a regional or (inter)national arena through various forms of scale and agglomeration advantages (Nijkamp 2016).

Countries, regions, and municipalities all over the world are exposed to the challenge and opportunity to improve continuously their position and to optimize their socioeconomic performance, by economizing on the use of critical (internal and external) resources to enter a more promising - though also more risky - competitive spatialeconomic environment in a globalizing system. Such a performance may comprise: welfare, socio-economic well-being, income, safety, employment, economic growth, (inter)national recognition, social cohesion, sustainable development, and so forth. It should be noted here that there is in general no unambiguous and measurable performance measure for such territories, in contrast to industrial organizations, where nowadays KPIs (key performance indicators) act as signposts for company strategies. Clearly, some attempts at designing such systematic information have been made in recent years. For example, in an urban context, the notion of XXQ (maximum quality of a city) has recently been advocated as an overarching policy objective including in particular economic, social, and ecological performance indicators of a city (see Nijkamp 2008, Kourtit 2014, 2015).

It seems plausible that any territory in the form of an interlinked spatial entity 
(country, region, municipality) seeks to optimize its relative position in a balanced way in order to achieve the highest possible quality of welfare, living, and working in this area (see Nijkamp 2008, Kourtit 2014, 2015), as compared to others. These 'others' may be the direct neighbors in the vicinity, but they may also be found at the international stage (see for instance, the competition between global world cities such as New York, London, Paris, or Tokyo) (we refer here, for example, to Kourtit et al. 2013, Arribas-Bel et al. 2013). Regions in our world may be assumed to maximize their contribution to - and share in - the total 'performance production' at a global scale, or at least within a given relevant continent or country. This performance ${ }^{1}$ may be measured on a multidimensional and even multilevel scale - including e.g., GDP per capita, employment, public facilities, socio-economic equality, and ecological quality as well as critical network elements - as part of a so-called 'Territorial Performance Index'(TPI), which may act as crucial location factors and drivers for various actors across geographical units (see also Camagni 2009). Such a TPI is clearly a latent variable and may be the result of either competitive strategies or cooperation initiatives, or both, with regard to players in the same domain (see also Healy, Cote 2001). In this context, Kaasa, Part (2008) argued that "an individual's achievements would be higher, if he or she competed and cooperated with others through different networks and common value systems" (p. 5). This also holds for territories (countries, regions, cities, etc.) which may be seen as multi-tasking production units, often in liaison with other territories.

In the light of the previous observations, we will assume in the present paper that each territory has a TPI which can be produced or created through a smart combination of various productive inputs, in particular, Human Capital (HC), Infrastructural Capital (IC) and Social Capital (SC) (see also Becker 2009, De la Fuente, Vives 1995, Heckman 2000, Ravikumar, Glomm 1992, Rodriguez-Pose, Fratesi 2004). The TPI production function is thus shaped through at least three distinct - but often mutually connected production factors. The welfare of regions is thus critically dependent on its resource use (Nijkamp 2016). The blend of these three categories of production inputs will be coined here 'Territorial Capital' (TC).

'Territorial Capital' is a new concept that has received much policy attention in the past decade (see OECD 2001, European Commission 2005). It takes its starting point in the unifying concept of a region which unites various productive forces (capital, labor, infrastructure, knowledge, innovation, resources, or social capital) that act as jointly operating production factors so as to increase regional productivity and efficiency and to sustain socio-economic growth. It may be defined as the set of geographically and locally bounded critical assets, amenities, and conditions that provide the competitive advantages of places and their uniqueness and attractiveness through an efficiencyenhancing contribution to sustainable growth (Camagni 2009). TC is thus not only geographically bounded, but also functionally related to a regional system (in material, social, technological, cultural, and cognitive terms). This idea was inspired by the seminal contributions of Camagni (2002, 2009) , Camagni, Capello (2011, 2013, 2015), Capello et al. (2011), Caragliu (2015), Fratesi, Perucca (2014), and Perucca (2014). This idea has first been introduced as an operational tool in the regional development literature by Camagni (2002) and has been followed by various subsequent empirical territorial capital studies (see for a survey, amongst others, Capello et al. 2011). The three constituents of TC can be briefly described as follows:

- Human capital (HC): knowledge, training, education, R\&D, learning-by-doing strategies, creativity, innovativeness, entrepreneurial attitude.

- Infrastructural capital (IC): physical transport and communication facilities, connected networks, energy grids, water facilities, ICT, digital information and moni-

\footnotetext{
${ }^{1}$ The 'performance' concept already has a long history in industrial management and business economics. In general terms, this concept can be defined as: 'a person's achievement under test conditions' (Oxford Encyclopaedic English Dictionary). However, in productivity and efficiency studies, this concept is defined much more broadly and refers to a systematic operational measurement - often in comparison with relevant actors - of the relevant economic achievement position of an actor or corporate organization (see also Kourtit 2014, 2015, p. 16). The latter meaning will also be adopted in our study on the aviation and aerospace cluster in the Podkarpackie region in South-East Poland.
} 
toring systems.

- Social capital (SC): communication networks, business alliances, incubators, sociocultural cohesion strategies, cooperation programs, knowledge spillover networks, voluntary organizations (NGOs, etc.).

The smart combination of these productive resources by a region leads to the unifying concept of a 'resourceful region', as advocated in Nijkamp (2016). It is clear that HC, IC, and SC are compound and multidimensional latent vectors, which can only indirectly be observed through measurable indicators (see Section 4). They determine in combination the TPI for each relevant area. In this context, an interesting research question with important regional policy implications concerns the effectiveness of enhancing and improving the regional cluster performance - of both the actors individually and the region as a whole - in producing a desired result on the basis of a smart (innovative and sustainable) use of territorial capital in the area concerned.

In our study we will provide an empirical test of this concept for the Podkarpackie region (voivodship) in South-East Poland. We will address in particular the question: "which territorial capital assets play an efficient role in the mechanism of an effective cluster in the Aviation Valley in this region?" This calls for a triple-layer analysis: (i) a comparative performance analysis of the Podkarpackie region in Poland as the home basis of aviation activities; (ii) a detailed spatial analysis of the counties ('powiats') in Podkarpackie, as the counties ('powiats') in this region are rather heterogeneous and offer different territorial capital assets, and (iii) a comparative study at the firm level to identify the attractiveness factors in the various counties for the individual firms in the Aviation Valley.

\section{The Aviation Sector in Poland}

\subsection{Transformation of the aviation industry in Poland ${ }^{2}$}

The airline sector (aviation sector) has over the past decades turned into one of the most dynamic, rapidly growing and high-tech oriented industries in the world, mainly as a consequence of deregulation and intense competition in this sector (see e.g. Adler, Golany 2001, Berechman, de Wit 1996, Burghouwt, Huys 2003, Button 2002, Nijkamp 1996). The demand drivers and the supply conditions of modern aviation have been extensively examined in the literature, in particular, the pricing and routing scheduling, as well as the airport operations. Less attention has been paid to the production and location aspects of aircraft and aircraft equipment and services. The latter - mainly manufacturing - issue has in recent years become an important component of modern regional cluster analysis and policy. Poland has historically been an important center of airplane production, until this sector collapsed after the fall of the iron curtain. Against the background of a dedicated regional policy, the aviation production sector has recently become one of the spearheads of policy support for the Aviation Valley in the Podkarpackie region in South-East Poland.

The history of the Polish aviation industry dates back to the 1930s, when several aviation companies were established in the Central Industrial Area (Centralny Okręg Przemysowy (COP)) in Poland. The transformation of the economic system in Poland in the early 1990's opened new possibilities for the - traditionally strong - Polish aviation industry, but created also several new obstacles that could have slowed down or even stopped its favorable development, if not bypassed effectively. One of the most important strategic decisions was outlining and deciding how the industry should be privatized by choosing and convincing strategic investors (companies which would provide significant investment capital) and by considering and implementing alternative methods of ownership transfer. It was essential to plan how the industry would enter into international cooperative agreements, while showing strength and competitiveness. Market opportunities existing at

\footnotetext{
${ }^{2}$ The authors wish to thank Zbigniew Bochniarz, Emilia Barbara Sieńko-Kułakowska, Grzegorz Pisarczyk and Waldemar Ratajczak for their great contribution to this section on the transformation and sustainable development of the aviation industry in Poland.
} 
the time indicated that Poland could take advantage of well-established aviation industry facilities and of past achievements, and build up a competitive advantage, particularly in the light-aircraft market. The historical presence of human capital and industrial engineering traditions in the Podkarpackie region - dating back to the pre-WWII period helped to encourage a revitalization of the aviation industry.

\subsection{Sustainable development of the aviation industry in Poland}

\subsubsection{A sketch of the industry}

The expansion of the Polish aviation industry after the transformational period in the 1990s appears to depend strongly on a combination of expansion of international industrial cooperation and foreign direct investment (FDI). As a result, the industry had a rich export offer in terms of advanced aviation products (or rather, sub-assemblies, components, parts, and equipment) for export to e.g., the USA, Venezuela, Indonesia, Italy, Greece, Canada, Spain, Germany, South Korea, and Vietnam. This led to a new and creative revival of industrial spirit and organization. Operating plants in this area are specialized in the production of aircraft components and services (high-tech, training, and executive services), helicopters, gliders, sub-assemblies (aluminum, composite, GRFP), and accessories. Over 140 businesses appeared to operate in 2015 in the Polish aviation and aviation-related sector, with approx. 1 billion EUR in annual sales, and 24,000 employees in total. The majority of these activities are composed of small and medium-sized businesses (SMEs), while companies are partly owned in some cases by foreign investors; there is also a small number of businesses that are owned by the National Treasury in Poland. The majority of the aviation facilities in Poland is located in the South-Eastern part of the country, mainly in a few existing clusters, in which the Aviation Valley in Podkarpackie is the most prominent one.

The biggest foreign investors in the Polish aviation industry are General Electric, United Technologies Corporation, EADS CASA, Pratt \& Whitney Canada, Goodrich, Hispano Suiza, and Avio (see Figure 1). The production potential of these businesses is high, mainly due to the quality of the products offered (thanks to a long-standing experience on how to treat materials, casting, mechanics, and electronics) and competitive labor costs. The currently existing network cluster of production and service companies supported by $R \& D$ centers have the potential to cooperate in fulfilling and referring orders of replacement parts and complete products for the aviation sector. Thanks to the contribution of companies to $\mathrm{R} \& \mathrm{D}$, collaboration with research centers and universities, participation in foreign projects, human capital, and the strongly developing clusters, the aviation sector is one of the most innovative ones in the whole Polish economy (see also Ratajczak 2008).

The growth of the aviation industry would not have been possible without qualified human capital. Every year over 11,000 engineers graduate from Polish technical universities, while about 650 graduates have a major in aviation. A highly developed university education system and on-the-job training systems, combined with a rich tradition of excellence, are factors that greatly improve the quality of aviation sector personnel, as is witnessed by the Triple-Helix constellation around the Rzeszow area. Additionally, thanks to new initiatives (such as AERONET), the aviation sector has achieved a close cooperation between industry, government, and educational institutions, serving the common goal of better preparing personnel, for example, by designing specialized educational programs and offering qualified majors to adequately fit the needs of the job market. Clearly, industry-university-policy interfaces appear to be a critical success factor for the growth of the aviation sector in Poland. For a strategy analysis of this phenomenon we refer to Kourtit, Nijkamp (2017).

\subsubsection{The Aviation Valley: the Dolina Lotnicza cluster}

The Polish aviation industry's prospects for economic and technological advancement are particularly dependent on strategies for effectively operating modern industrial aviation clusters. A promising role model for such a strategy may be found in the Aviation 


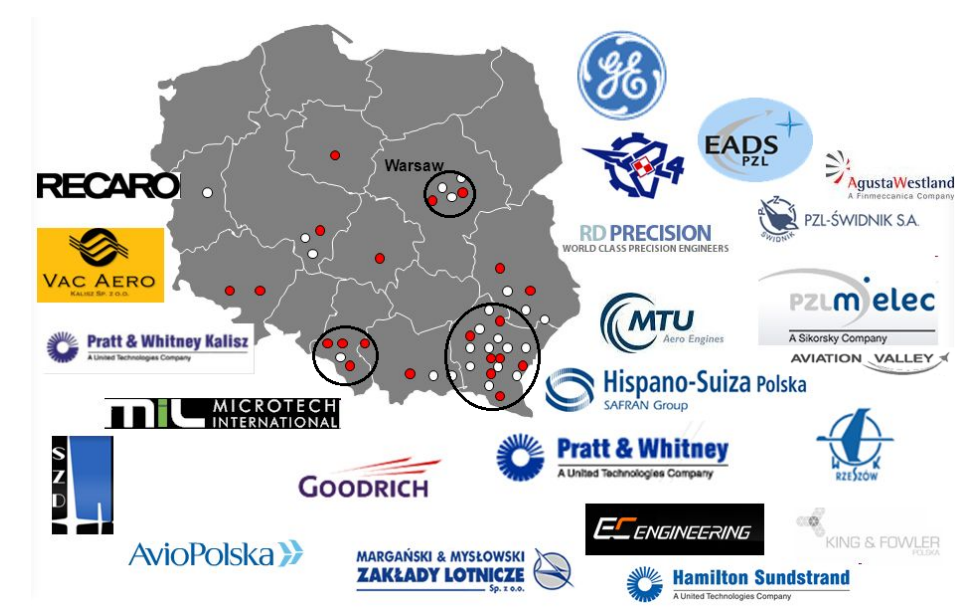

Source: Internal documents from the Aviation Valley (Dolina Lotnicza) cluster and Marshall Office Notes: Encircled areas are aviation regions in Poland, in which the Aviation Valley in the South-East is the dominant one

Figure 1: The aviation industry in Poland

Valley (Dolina Lotnicza) cluster in this country. This cluster contains over 100 innovative manufacturing businesses responsible for a large number of aviation products such as components, major assemblies, and sub-assemblies for jet engines, gliders, and helicopters, produced for some of the most important aviation manufacturers and users in the world. Companies in the Aviation Valley are also responsible for the manufacturing of finished products for final clients. Many of the companies in the cluster work together to fulfill their project's tasks in an efficient way, while also a number of businesses complete their entire manufacturing process using only their own resources and offering their products directly to the market. The Aviation Valley represents nowadays about $90 \%$ of the aviation industry in Poland. Associated partners are worldwide leaders in their respective fields, such as Pratt \& Whitney, Sikorsky, Agusta Westland, Hispano Suiza Polska, Goodrich, MTU Aero Engines, Hamilton Sundstrund, and a dozen of small and medium-sized businesses (see again Figure 1).

A critical challenge in developing this cluster was to bring also small and medium-sized businesses with a commercial link to aviation into the cluster, including those with Polish and foreign investment sources. Through the flow of - and access to - new technologies, these businesses are able to achieve ambitious cooperative goals in the cluster. The realization of such industrial processes means essentially a shift of various activities in the value chain towards the center of the cluster. Experiences from other big clusters indicate that such undertakings lead to effective and high synergy and to measurable economic benefits. The Aviation Valley in Poland has indeed managed to include a large number of critical market and technological leaders among its cluster participants, who continue to bring their added value into the cluster. Consequently, a characteristic of the Aviation Valley cluster is the emergence of a fully developed value chain, as depicted in Figure 2 which shows the structure of the cluster (see also Kaszuba 2012).

The various R\&D, production, and market operations in the Aviation Valley cluster have been a model of cooperation between industry and research in Poland. For example, aviation manufacturers meet regularly with representatives of the best Polish technical universities and research centers that have partnered with them. It is noteworthy that among the businesses originating from the Polish aviation industry, only a few large companies (e.g., PZL Mielec, EADS PZL, PZL-Świdnik) produce final goods. Small and medium-sized businesses operate mainly in a cooperative and/or subcontractor role, producing only specific elements of the airframe and equipment of airplanes, or building specialized aircraft parts. However, subcontractors and suppliers are not the only small businesses which play an important role. There are also other small firms that build their own aviation designs, including technologically advanced small aircraft and gliders. 


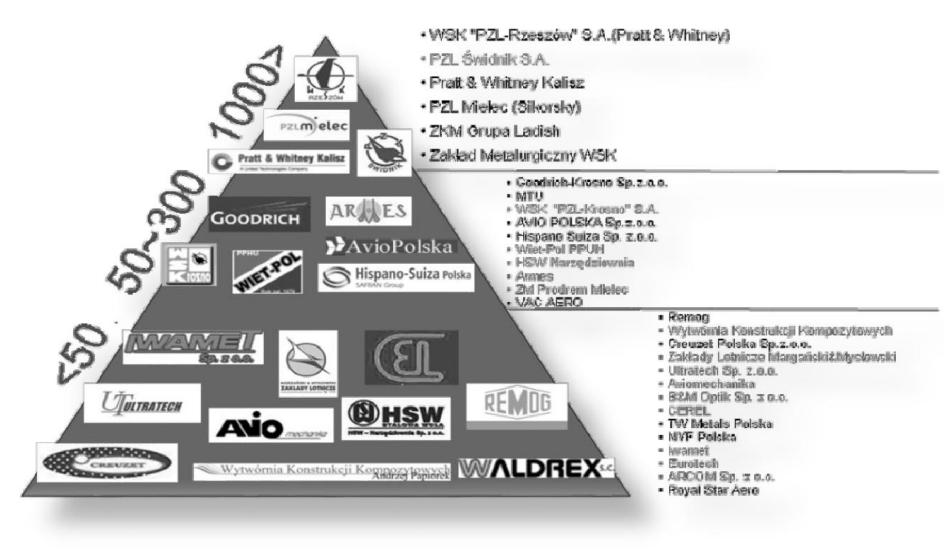

Source: Internal documents from the Aviation Valley (Dolina Lotnicza) Cluster and Marshall Office Notes: Companies divided by employment level (scale on the left axis)

Figure 2: The structure of the Aviation Valley (Dolina Lotnicza) cluster in Poland

The total sales of all businesses in the aviation sector in Poland have been steadily rising, with the Podkarpackie region as the uncontested leader. The sector has been growing drastically, with sales even quadrupling in the years 2003-2008. This dynamic development is closely linked to foreign investments, as the majority of sales are the result of supplying foreign companies which own or contract these Polish manufacturers.

It is also clear that the presence of and access to an advanced knowledge base in the Podkarpackie area - in particular, higher education institutes - play a critical role in supporting new technology industries (see Calzonetti, Reid 2013). R\&D plays a critical role in the success of the Polish aviation industry in general and of Dolina Lotnicza in particular. As a world-class cluster, it has a main goal to conduct advanced academic R\&D as well as establishing innovative solutions in the field of aviation engineering (European Aeronautics 2001). Clearly, the Polish aviation industry does currently not yet participate in large-scale manufacturing of passenger planes. This has significant implications for the development of a new model of cooperation with the few world leaders shaping their global supply chain. It influences also the scientific and technological research of the Polish aviation industry and forces it to retain its competitive niche position (Baczko 2011). It is noteworthy that also the Polish job market may be strengthened in the future by a highly qualified workforce able to develop, design, and build high-quality and highly innovative aviation subcomponents and complete products. We will now address the framing of the critical success factors and conditions for this creative aviation development in this region in Poland.

\section{A Triple-Layer DEA Model for the Aviation Valley}

\subsection{Introduction}

The notion of an industrial cluster has gained much popularity over the past two decades (see Porter 1990). Recent contributions to cluster concepts and policies can be found inter alia in Asheim et al. (2006), Kasabov, Sundaram (2016), and Scholl, Brenner (2016). As mentioned in Section 1, a cluster may be seen as a complement to earlier concepts from the regional-economic growth literature, such as industrial districts, industrial corridors, growth centers, or development axes (see also a recent contribution by Gibson et al. 2013, Nijkamp 2016). The Aviation Valley - called Dolina Lotnicza in Polish - is a rapidly growing industrial cluster, but needs still further development, in terms of both widening and deepening. In order to become an 'effective cluster' - well anchored in the region on the basis of cooperative strategies ('social capital') and through advanced cognitive and technological applications - in a regional development context, new initiatives are needed, based on entrepreneurship, leadership, and good governance at local and regional levels. 


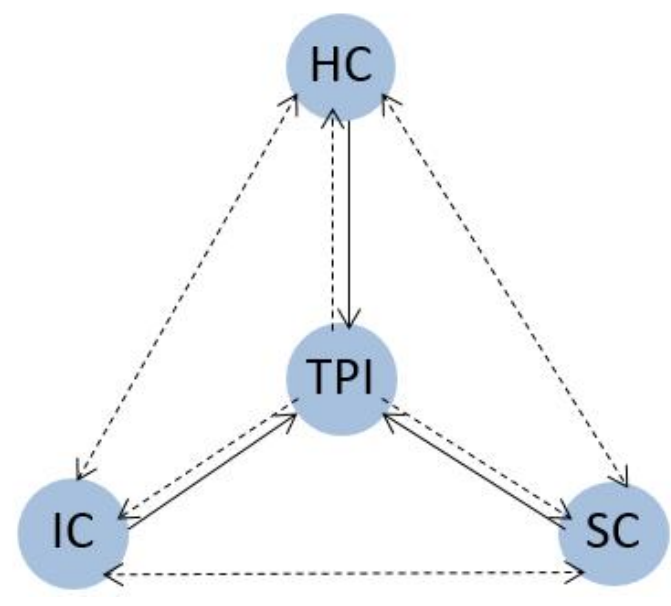

Source: Authors' design

Figure 3: Scheme of the TPI production function (positive externalities for effective cluster performance)

The basic idea of an effective cluster - sketched out in Figure 3 - is that it enhances economic performance of each cluster participant and of the cluster as whole through a smart combination of human, social, and infrastructural capital ${ }^{3}$. Such a cluster is thus driven by positive externalities and may be seen as a flagship for successful regional development.

The Polish aerospace cluster contains more than 100 firms and at present over 1 billion EUR annual revenues, with a concentration in Podkarpackie. This flagship project hosts all major global aviation manufacturers, but still needs a further strengthening and more synergy in order to become an effective and efficient industrial agglomeration, as highlighted in the seminal writings of Marshall, Isard and Porter, to mention only a few.

Industrial clusters are often spontaneously emerging, thematically oriented industrial concentrations, but they may also be the result of dedicated policy decisions to favor a certain industrial concentration in a given region. In both cases, there is a need for informed stimulating policies so as to maximize cluster benefits through innovativeness, productivity increase, and smart specialization. In the specific case of the Aviation Valley, there has been a long tradition of aerospace activities which have been an undercurrent for a rejuvenation of this sector in the past decades after the fall of the iron curtain. Clearly, there is also a need for applied statistical and econometric techniques for testing, understanding and assessing a cluster's performance.

The aim of the present section is to design a systematic and operational framework to provide an original analysis of the cluster achievement data, based on the above mentioned triple-layer architecture, by using an extended and stepwise Data Envelopment Analysis (DEA) to position these regions (voivodships), counties (powiats) and firms on the basis of their relative performance, i.e. by relating their multiple outputs to multiple inputs in the context of an effective cluster to be attained through a balanced mix of HC, IC, and SC, next to the business achievements of individual cluster participants and of the cluster as whole (see also Kourtit, Nijkamp 2013a). We will now offer the design of a conceptual model for an effective cluster assessment in our analysis (see Figure 3).

Figure 3 sketches out the central research aim of the present paper: the assessment of the territorial performance of an advanced industrial area (i.e., an effective cluster) as a function of its human, infrastructural, and social capital provisions (i.e., its total

\footnotetext{
${ }^{3}$ A comprehensive definition of an effective cluster is: "A geographical and tangible concentration of advanced economic, technological and social activities - both private and public - in a given region, that is driven by synergy coming from network of actors committed (social capital) and usually supported by public policy in order to enhance the cluster performance (in particular, competitiveness, innovation, shared values and trust) - of both the actors individually and the region as a whole - on the basis of a smart (innovative and sustainable) use of territorial capital in the area concerned" (www.effectiveclusters.eu).
} 
territorial capital). The validity and relevance of this TPI methodology will now be tested by means of an application to the Aviation Valley in the Podkarpackie region in South-East Poland, which aspires to become a leading high-tech region in the field of the aviation industry in Europe. We will test our conceptual TPI model on the basis of a triple-layer and a (super-efficient) DEA model using a wide array of empirical data on this Aviation Valley and the territorial capital of the region and of the constituent areas concerned.

It is thus clear that Territorial Capital (TC) is a basket of areal productive assets in an effective cluster composed of Human Capital (HC), Infrastructural Capital (IC), and Social Capital (SC). These three constituents make up the production inputs for the Territorial Performance Index (TPI) in our Data Envelopment Analysis (DEA). Given the large multidimensional databases, the use of a multivariate statistical analysis is a necessary tool in the triple-layer approach in our study so as to obtain a systematically structured database.

\subsection{Principal Component Analysis (PCA)}

Our triple-layer database contains a wide variety of important statistical factors which determine the quantitative performance of a DMU, at each of the three levels of our analysis (voivodship, powiats and firms). This set of multiple indicators contains at each level an extensive set of multicollinear variables, so that it would be hard to draw straightforward and unambiguous conclusions on the underlying causal mechanisms. Therefore, it was necessary to apply a multivariate analysis - in this case, a principal component analysis - to identify uncorrelated and mutually independent factors, which can be used as proxies for the determinants of regional growth.

In the particular case of detailed statistical information on the 16 voivodships in Poland, we have a broad and detailed annual database (population, labor market, economic variables, etc.) on all voivodships and powiats. Clearly, this leads to a case of multicollinearity in our data. To avoid statistical biases, we used a principal component analysis (PCA), so that we are able to distil from a multicollinear data set a new set of transformed and independent variables that do not suffer from multicollinearity. The next step in our triple-layer analysis was to apply a DEA to each of the three constituents of our database.

\subsection{Data Envelopment Analysis (DEA)}

DEA has become an established method in management sciences and industrial organization theory to assess the efficiency of complex organizations, often referred to as Decision Making Units (DMUs). It finds its origin in activity analysis and multiple objective programming, and aims to identify in a comparative sense the relative efficiency of DMUs on the basis of their output versus input ratios, in multiple dimensions. So, DEA is essentially a generalized productivity analysis.

The standard DEA model was developed by Charnes et al. (1978) (usually abbreviated as the CCR model). This model - and its many variants and extensions - has found thousands of applications in the scientific literature over the past decades. We refer here to various overview publications, such as Charnes et al. (1994), Zhu (2003), Färe et al. (1998), Ray (2004), Cooper et al. (2006), Zhu, Cook (2007), Suzuki, Nijkamp (2016a,b), Susuki, Nijkamp (2017), and Suzuki et al. (2010, 2015).

The result of a DEA analysis is normally a ranking of DMUs according to their degree of output efficiency. In this way, it is not only possible to find the position of each individual DMU on the efficiency ladder, but also to find out which inputs should be changed, so as to obtain a more efficiently operating organization. There is a great variety of DEA models, starting from the basic CCR model originally developed by Charnes et al. (1978). Over the past decades, a whole range of adjustments and revisions have been implemented, so as to cope with weak elements, limitations, or specific needs of DEA model applications (see Susuki, Nijkamp 2017). We will use here an adjusted version of a standard DEA model, namely a Slack-Based Measure (SBM) - in a triple-layer architecture - to identify the relative efficiency of voivodships, powiats and aviation 
business firms in Poland, in order to draw conclusions on the success conditions of the aviation sector in this country and its regions and counties.

In the context of the triple-layer constellation of smart or effective cluster policy in Poland, the so-called Slack-Based Measure (SBM) model turned out to provide a meaningful tool for performing a DEA analysis at three consecutive levels of DMUs, viz. voivodships, powiats, and enterprises. The SBM model was initially developed by Tone (2001) and has found various interesting applications in the literature.

The main distinction between the standard CCR model and the SBM model is related to a radial type projection model and non-radial type model, respectively. A shortcoming of the radial model is a neglect of slacks in computing the efficiency score. Consequently, the radial type model may lead to a biased and overestimated efficiency score. In contrast, the non-radial type models including SBM are able to deal with a slack presence. Hence, an SBM model can improve the overestimation problem.

We will next, in the application of the triple-layer SBM DEA model, include one more extension, viz. the concept of super-efficiency. In the standard DEA model, DMUs located on the efficiency frontier are all equally efficient and hence receive an efficiency score of 1 . In many cases, it is desirable to make a further distinction among these efficient firms with an equal score of 1 . This has prompted the notion of super-efficiency (SE), through which an unambiguous ranking of DMUs can be achieved (see Tone 2001). We will present here the results of a combined SBM-SE model in our DEA of the Aviation Valley in Poland.

In our empirical DEA application, we will use the (transformed PCA) data on HC, IC, and SC as inputs for a DEA exercise in each of the three stages, while we will use the TPI as output (or performance indicator), based on the architecture of our model sketched in Figure 3. In conclusion, we position PCA and DEA in the context of our triple-layer explanatory model for the performance of relevant DMUs in the aviation industry in the Polish Aviation Valley.

\subsection{Conceptual framing of territorial performance in DEA}

\subsubsection{Architecture of the model}

The constituents of the Territorial Performance Index (TPI), viz. HC, IC, and SC, have been outlined in previous sections, based on the schematic presentation in Figure 3. We will, in the present subsection, integrate these building blocks into a more comprehensive TPI framework, by first extending the basic Figure 3 with the most prominent functionalities of the three capital categories under consideration (see Figure 4).

The functional-causal linkages among HC, IC, and SC can be used as the building blocks for a more comprehensive operational model that maps out the total factor productivity (TFP) of the determinants of regional development. A schematic presentation of this model can be found in Figure 4.

It should be added, that next to these contextual capital assets from the business environment in the region, the territorial performance of a region is also determined by the business efforts and subsequent performance actions of private firms in the cluster. The latter category may comprise KPIs of the private sector in the region under consideration. We will now describe in slightly more detail the various explanatory constituents in our TPI production function.

\subsubsection{Human Capital}

Human capital has become an important topic in economic research since the seminal contributions of Schultz (1961) and later on by Becker (2009). It is nowadays seen as a crucial factor for economic growth and efficiency. Human capital (HC) comprises the personal characteristics and cognitive skills of people who share the responsibility for regional development in a given area. $\mathrm{HC}$ is a multi-dimensional concept which includes inter alia: cognitive skills, training facilities, educational programs, advanced knowledge use, R \& D expenditure, technical support programs, creativity, human health 


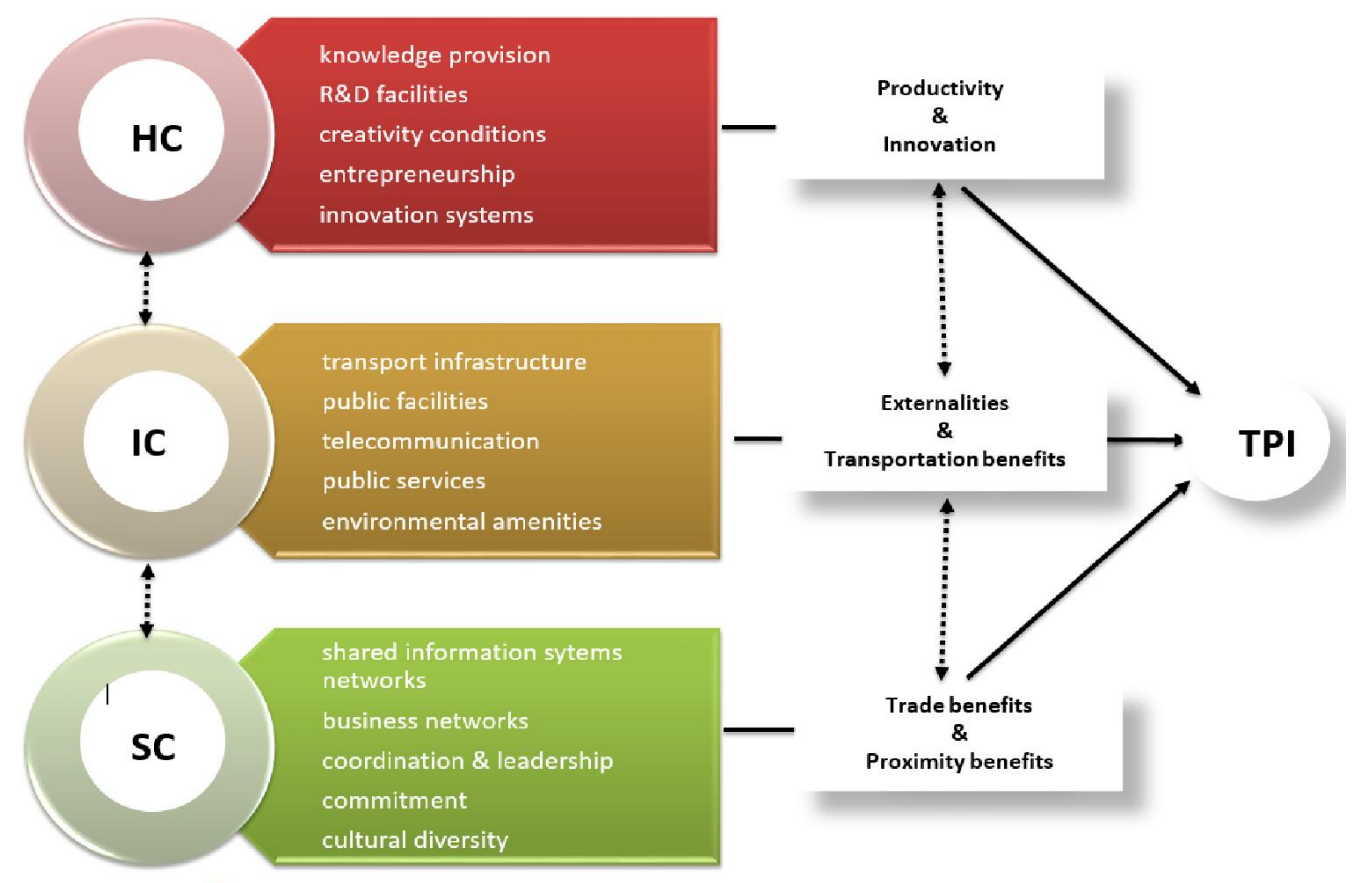

Source: Authors' design

Figure 4: A comprehensive representation of the TPI model

conditions, learning experiences, organizing capacity, innovativeness, open innovation systems, entrepreneurship, etc.

\subsubsection{Infrastructural Capital}

Infrastructure is often regarded as a prominent factor in regional-economic development, in both developed and developing economies (Aschauer 1989, Bröcker, Rietveld 2009, Elburz et al. 2015). Infrastructural capital (IC) refers to the necessary physical and material conditions in the form of public or collective goods that shape or induce the welfare of a country or region. Infrastructure may be instrumental in accelerating economic growth and mitigating spatial disparities. It may adopt various forms, e.g., land transport infrastructure, air and water transport facilities, public amenities and telecommunication. Examples are: roads, streets, parking facilities, railways, railway stations, public transport facilities, airports, runways, ports, energy grids, telecommunication facilities, public services (e.g. health care), environmental amenities, tourist and recreational facilities, etc. The assessment of the impact of IC on regional development calls generally for a broad multidimensional impact model (see e.g., for a general survey and meta-analytical synthesis Celbis et al. 2015).

\subsubsection{Social Capital}

Social capital is a more recent concept in economic research. It found its origin in sociological research and was first advocated by Hanifan (1916), who described social capital as: "Those tangible assets [that] count for most in the daily lives of people: namely goodwill, fellowship, sympathy, and social intercourse among the individuals and families who make up a social unit" (p. 130). Later on, it was further popularized inter alia by Jacobs (1961), Bourdieu (1981), Coleman (1988) and Fukuyama (2001).

Putnam (1993) offers a more contemporaneous definition: "Social capital refers to features of social organization, such as networks, norms, and trust, that facilitate coordination and cooperation for mutual benefit" (p. 35). Social capital plays a critical role in 
Table 1: The multivariate database (reduced into a single-period database with two independent factors by means of a PCA) for the 16 voivodships in Poland ${ }^{5}$

\begin{tabular}{lccr}
\hline Regions & \multicolumn{2}{c}{ INPUTS } & OUTPUT \\
& HC & IC & GDP \\
\hline EÓDZKIE & 15.24383785 & 17.76018463 & 101423 \\
MAZOWIECKIE & 59.36306148 & 1 & 364513 \\
MAŁOPOLSKIE & 27.573995 & 17.73570387 & 128009 \\
ŚLA_SKIE & 35.9421777 & 37.32693562 & 207104 \\
LUBELSKIE & 9.357115528 & 13.42869107 & 65845 \\
PODKARPACKIE & 7.993997384 & 12.56609439 & 65365 \\
PODLASKIE & 3.351309907 & 6.687236914 & 37601 \\
SWIETOKRZYSKIE & 5.554316221 & 17.32539808 & 40047 \\
LUBUSKIE & 1 & 11.88567379 & 36940 \\
WIELKOPOLSKIE & 22.30567904 & 18.32329266 & 161485 \\
ZACHODNIOPOMORSKIE & 9.306254571 & 13.49000607 & 62463 \\
DOLNOŚLA_SKIE & 22.36283317 & 14.45307287 & 140901 \\
OPOLSKIE & 4.482978925 & 20.22856136 & 35130 \\
KUJAWSKO-POMORSKIE & 10.08726379 & 18.42180737 & 74515 \\
POMORSKIE & 18.02637696 & 11.99428224 & 95701 \\
WARMIŃSKO-MAZURSKIE & 2.997127294 & 12.4321011 & 45008 \\
\hline
\end{tabular}

Source: Source: Authors' own calculation using data from the Statistical Office in Rzeszow (2014)

regional development through the following channels: cooperation among actors, information sharing, trust and honesty, open communication channels, network connectivity, acceptance of coordination or leadership, socio-economic links, cultural bonds and bridges, social commitment, respect for others' values, duty performance, reliability, etc. It goes without saying that the measurement of social capital in an operational explanatory framework is fraught with many difficulties and needs usually the consideration of many variables.

After this description of concepts and data we will now proceed with our analysis and present the database for our triple-layer DEA applications.

\section{Information Collection}

\subsection{Statistical databases}

A wealth of statistical information has been collected on regional development in Poland and in the Podkarpackie region, the home base of the Aviation Valley ${ }^{4}$. These data concerned in the first stage the determinants and characteristics of regional welfare in each of the 16 voivodships in Poland in a detailed manner. This macro-regional exploration led to the composition of an extensive multivariate database, with more than 70 indicators comprising five-grained information on the components of Territorial Capital (TC), systematically subdivided into Human Capital (HC), Infrastructural Capital (IC), and Social Capital (SC) (according to the framework in Figures 1 and 2). This multivariate database on $\mathrm{HC}$, IC, and SC indicators was next transformed into a structured database containing two independent factors by means of a principal component analysis (PCA). The endogenous variable employed here (i.e., TPI) is GDP per capita (see Table 1), which is assumed to be determined by the two main components in this table.

The input factors - represented here as two independent vectors after a multivariate

\footnotetext{
${ }^{4}$ The database for the Aviation Valley study in Poland has been collected in the framework of a research project Effective Clusters - Basis for Innovation and Source of Sustainable Regional Development. The authors wish to thank Krzysztof Kaszuba for his advice on the sources of secondary data, Emilia Barbara Sieńko-Kułakowska and Grzegorz Pisarczyk for their great assistance in collecting primary data, and Waldemar Ratajczak for advice on the various research steps. The detailed source data are contained in the relevant background documents for this project.
} 
Table 2: The multivariate database (reduced into a single-period database with 3 independent factors by means of a FPCA) for the 25 powiats in the Podkarpackie region

\begin{tabular}{|c|c|c|c|c|}
\hline POWIATS & $\mathrm{SC}$ & INPUTS & $\mathrm{HC}$ & $\begin{array}{c}\text { OUTPUT } \\
\text { Average monthly } \\
\text { gross wages and } \\
\text { salaries }(\mathrm{zl})\end{array}$ \\
\hline BIESZCZADZKI & 823.34 & 12.18 & 84.54 & 3237.17 \\
\hline BRZOZOWSKI & 964.54 & 59.7 & 84.66 & 2964.62 \\
\hline JASIELSKI & 713.27 & 66.86 & 121.14 & 3038.82 \\
\hline KROSNIENSKI & 954.48 & 74.88 & 66.34 & 2887.05 \\
\hline SANOCKI & 584.01 & 23.32 & 92.91 & 3078.45 \\
\hline LESKI & 480.87 & 41.48 & 121.76 & 3283.39 \\
\hline M.KROSNO & 578.93 & 281.42 & 266.59 & 2980.59 \\
\hline JAROSLAWSKI & 535.03 & 75.96 & 131.29 & 3328.63 \\
\hline LUBACZOWSKI & 513.1 & 36.96 & 93.7 & 2951.96 \\
\hline PRZEMYSKI & 1423.3 & 43.62 & 57.41 & 3036.69 \\
\hline PRZEWORSKI & 647.76 & 87.34 & 86.93 & 2931.78 \\
\hline M.PRZEMYSL & 487.39 & 237.84 & 174.27 & 3325.5 \\
\hline KOLBUSZOWSKI & 939.97 & 68.46 & 62.57 & 2929.58 \\
\hline LANCUCKI & 613.6 & 135.86 & 97.73 & 2890.03 \\
\hline ROPCZYCKO-SEDZISZOWSKI & 586.34 & 72.52 & 103.49 & 3138.68 \\
\hline RZESZOWSKI & 962.87 & 100.36 & 74.59 & 3070.98 \\
\hline STRZYZOWSKI & 525.57 & 62.96 & 75.23 & 2786.37 \\
\hline M.RZESZOW & 1168.8 & 343.04 & 232.39 & 3859.86 \\
\hline DEBICKI & 711.79 & 89.38 & 103.39 & 3165.79 \\
\hline LEZAJSKI & 686.66 & 69.5 & 104.19 & 3146.29 \\
\hline MIELECKI & 717.79 & 82.04 & 114.9 & 3329.68 \\
\hline NIZANSKI & 746.86 & 61.32 & 70.86 & 2890.57 \\
\hline STALOWOWOLSKI & 650.9 & 92.46 & 122.86 & 3360.58 \\
\hline TARNOBRZESKI & 828.56 & 81.6 & 78.74 & 3326.4 \\
\hline M.TARNOBRZEG & 536.3 & 145.88 & 153.09 & 3200.51 \\
\hline
\end{tabular}

Source: Source: Authors' own calculation using data from the Statistical Office in Rzeszow (2014)

transformation from $\mathrm{HC}, \mathrm{IC}$, and $\mathrm{SC}$ - are the control variables to achieve an output value. Consequently, this data set from stage 1 can be used for an efficiency evaluation by means of DEA.

In the next (meso) layer, viz. the level of the 25 'powiats' (counties) within the Podkarpackie region, a similar approach was adopted, which led again to the composition of three independent factors from SC, IC, and HC, acting as drivers of regional welfare in these counties, while again output or GDP per capita (in terms of average monthly gross wages and salaries) was used as the dependent TPI variable (see Table 2).

Given the rich database at a county level in the Podkarpackie region, in this case the multivariate statistical PCA was separately applied to each of the multidimensional constituents of the $\mathrm{HC}, \mathrm{IC}$, and TC indicators in the respective area.

In the third and last (micro) layer, an extensive database was collected on the drivers and perceptions of the individual firms based in the Aviation Valley and located in different powiats in Podkarpackie. This database was the result of semi-structured and often time-consuming detailed interviews with the top managers of these firms, as well as with many other stakeholders. The firms under consideration were both large firms and SMEs. We will now offer a concise description of the elements of the latter database (see also Table 3).

The interview questions covered a wide range of business activities, such as industrial products, forward and backward linkages, service provision, employee types and size, profitability conditions, growth figures, HRM, management structures, links with local 
Table 3: Database on drivers and perceptions of individual firms based in the Aviation Valley and located in different powiats in the Podkarpackie voivodship

\begin{tabular}{|c|c|c|c|c|c|c|c|}
\hline FIRMS & FA1OU & FA2OU & $\mathrm{SC}$ & $\mathrm{IC}$ & $\mathrm{HC}$ & F1I & F2I \\
\hline AT1 & 3 & 5 & 650.9 & 92.46 & 122.86 & 2 & 3 \\
\hline BE2 & 5 & 4 & 1168.8 & 343.04 & 232.39 & 5 & 4 \\
\hline CA3 & 4 & 4 & 536.3 & 145.88 & 153.09 & 4 & 3 \\
\hline HE3 & 2 & 3 & 962.87 & 100.36 & 74.59 & 5 & 2 \\
\hline HI4 & 5 & 4 & 586.34 & 72.52 & 103.49 & 3 & 4 \\
\hline MA5 & 5 & 6 & 717.79 & 82.04 & 114.9 & 5 & 3 \\
\hline MT6 & 5 & 4 & 962.87 & 100.36 & 74.59 & 3 & 4 \\
\hline PZ6 & 6 & 6 & 717.79 & 82.04 & 114.9 & 5 & 5 \\
\hline TH7 & 6 & 4 & 650.9 & 92.46 & 122.86 & 4 & 5 \\
\hline TR8 & 5 & 6 & 613.6 & 135.86 & 97.73 & 5 & 4 \\
\hline UT9 & 5 & 3 & 578.93 & 281.42 & 266.59 & 4 & 3 \\
\hline WS10 & 6 & 6 & 1168.8 & 343.04 & 232.39 & 5 & 4 \\
\hline ZM11 & 5 & 5 & 1168.8 & 343.04 & 232.39 & 5 & 4 \\
\hline AD12 & 5 & 5 & 939.97 & 68.46 & 62.57 & 3 & 4 \\
\hline AE13 & 5 & 6 & 578.93 & 281.42 & 266.59 & 4 & 5 \\
\hline AE14 & 5 & 6 & 717.79 & 82.04 & 114.9 & 4 & 5 \\
\hline AI15 & 5 & 5 & 962.87 & 100.36 & 74.59 & 4 & 4 \\
\hline AR16 & 5 & 0 & 1168.8 & 343.04 & 232.39 & 3 & 6 \\
\hline AS17 & 5 & 5 & 1168.8 & 343.04 & 232.39 & 4 & 4 \\
\hline BM18 & 4 & 5 & 962.87 & 100.36 & 74.59 & 4 & 5 \\
\hline BO19 & 5 & 6 & 717.79 & 82.04 & 114.9 & 5 & 4 \\
\hline BR20 & 6 & 6 & 613.6 & 135.86 & 97.73 & 4 & 5 \\
\hline $\mathrm{C} 021$ & 4 & 3 & 1168.8 & 343.04 & 232.39 & 3 & 4 \\
\hline EL22 & 5 & 6 & 1168.8 & 343.04 & 232.39 & 4 & 4 \\
\hline EU23 & 5 & 5 & 717.79 & 82.04 & 114.9 & 4 & 5 \\
\hline FI24 & 4 & 1 & 939.97 & 68.46 & 62.57 & 3 & 3 \\
\hline FL25 & 5 & 5 & 717.79 & 82.04 & 114.9 & 4 & 5 \\
\hline FO26 & 1 & 5 & 686.66 & 69.5 & 104.19 & 1 & 1 \\
\hline GU27 & 5 & 6 & 586.34 & 72.52 & 103.49 & 5 & 4 \\
\hline HA 28 & 5 & 5 & 717.79 & 82.04 & 114.9 & 2 & 2 \\
\hline IN29 & 5 & 6 & 650.9 & 92.46 & 122.86 & 3 & 5 \\
\hline IW30 & 5 & 6 & 650.9 & 92.46 & 122.86 & 4 & 5 \\
\hline KA31 & 5 & 0 & 717.79 & 82.04 & 114.9 & 3 & 5 \\
\hline MA32 & 3 & 5 & 1168.8 & 343.04 & 232.39 & 3 & 3 \\
\hline MA33 & 4 & 5 & 717.79 & 82.04 & 114.9 & 3 & 4 \\
\hline MC34 & 5 & 5 & 962.87 & 100.36 & 74.59 & 4 & 3 \\
\hline ME35 & 4 & 5 & 962.87 & 100.36 & 74.59 & 3 & 5 \\
\hline MI36 & 5 & 5 & 578.93 & 281.42 & 266.59 & 2 & 2 \\
\hline NO37 & 6 & 5 & 1168.8 & 343.04 & 232.39 & 4 & 4 \\
\hline PO38 & 4 & 3 & 650.9 & 92.46 & 122.86 & 3 & 3 \\
\hline PO39 & 5 & 5 & 962.87 & 100.36 & 74.59 & 4 & 5 \\
\hline PZ40 & 5 & 5 & 711.79 & 89.38 & 103.39 & 2 & 4 \\
\hline RE41 & 6 & 6 & 717.79 & 82.04 & 114.9 & 5 & 6 \\
\hline R042 & 5 & 5 & 717.79 & 82.04 & 114.9 & 2 & 4 \\
\hline SE43 & 6 & 5 & 525.57 & 62.96 & 75.23 & 4 & 4 \\
\hline SP44 & 4 & 3 & 717.79 & 82.04 & 114.9 & 3 & 4 \\
\hline TW45 & 5 & 4 & 962.87 & 100.36 & 74.59 & 3 & 1 \\
\hline UN46 & 4 & 5 & 711.79 & 89.38 & 103.39 & 4 & 4 \\
\hline WA47 & 5 & 5 & 717.79 & 82.04 & 114.9 & 3 & 5 \\
\hline WI48 & 6 & 6 & 578.93 & 281.42 & 266.59 & 4 & 4 \\
\hline WS49 & 4 & 2 & 578.93 & 281.42 & 266.59 & 3 & 3 \\
\hline WY50 & 5 & 5 & 586.34 & 72.52 & 103.49 & 2 & 3 \\
\hline ZE51 & 5 & 5 & 962.87 & 100.36 & 74.59 & 3 & 4 \\
\hline ZP52 & 5 & 6 & 717.79 & 82.04 & 114.9 & 5 & 6 \\
\hline
\end{tabular}

Source: Authors' own calculation using data from interviews in Podkarpackie Voivodship, powiats and gminas (2014) and data of different powiats in the Podkarpackie voivodship from the Statistical Office in Rzeszow (2014)

Notes: Firm names are strictly confidential and therefore anonymized; FA1OU: General growth; FA2OU: Export and revenues; F1I: Strong network and innovation sources; F2I: Cooperation and competitiveness 
authorities, cluster linkages, internationalization, etc. The interviews were organized for four distinct groups of business entities of the most important firms and agencies located in the Aviation Valley. We will provide a brief account of these interviews.

The first group consists of large companies which are the main producers for the global airline industry and are closely linked with their parent companies abroad. The second group comprises small and medium-sized companies with a production profile that is partly related to the airline industry and that is linked in a supply chain to large aviation companies in the region. The third group of interviewees addressed institutions of a supporting nature for the aviation business, e.g., universities, consultation and certification institutions, agencies for regional development (all members of the so-called Aviation Valley Association); these organizations are linked to other members of the Aviation Valley Association by providing advisory, training and certificate services, and by jointly carrying out R\&D projects. Finally, the last group of interviewees is composed of companies and institutions of a varying legal or administrative status as well as of local and regional authorities related to the Aviation Valley Association, with an external common value chain; examples of such participants are inter alia: institutions with various levels of education - mostly colleges and universities - , banks and financial institutions, local administrations at various levels, other smaller clusters operating in the region, training and consulting companies, and so forth.

As mentioned above, four different types of surveys were designed, while also in-depth survey questions adjusted to specific classes of respondents were added. Clearly, this research task contained a multiplicity of appropriate survey questions geared towards each group of respondents so as to make a comprehensive diagnosis for all respondents in the Aviation Valley whenever possible. In the case of the first two groups of business firms, the survey questions were similar, so that it was possible to compare results which are common to every surveyed company within the cluster, so as to arrive at a consistent interpretation of the results. Our survey questions were designed in a flexible and open way, so that a wide range of specific planning issues for the region could be addressed. Questions were grouped according to a systematic typology of topics, so that the analysis of various questions could provide systematic information on the scope of the research. Clearly, the survey among business firms is to be treated anonymously and its results are used here as summary data without any possibility to identify individual companies which answered particular questions. A total of 55 companies - members of the cluster took part in the survey.

The primary sources of statistical information were thus supported and complemented by confidential survey research conducted on a group of general companies/institutions cooperating in and with the Aviation Valley Association. The choice of respondents was conditioned by the range of cooperation and the cluster's influence on its economic and technological environment. Therefore, among the institutions and companies interviewed were: (1) financial institutions (banks, insurance companies, support institutions), (2) institutions related to environmental protection and ecology (including informal associations), (3) local government agencies, (4) political parties, (5) energy power companies, (6) transport and logistics companies, (7) local marketing and PR institutions, (8) nongovernmental organizations, (9) other local clusters, (10) schools and training institutions, (11) government agencies supporting the cluster activities, and (12) others, e.g., service companies dealing with quality management, human resources management, provision of telecommunication services, and so forth.

The above survey encompassed in total 35 service institutions operating in the Aviation Valley Association environment. It was directed to a total of 73 potential respondents. The response rate for this survey was $48 \%$. The specific results from the group survey questions concerned: general knowledge about the Aviation Valley Association, evaluation of cooperation intensity between the respondent and the cluster (and its members), barriers in the area of business connections, potential motives for entering the cluster, affiliation with other cluster structures and its benefits, evaluation of strategic operations, and marketing and communication of the Aviation Valley Association. Moreover, there were also questions concerning the evaluation of the potential of the region to attract new firms, to further develop a company or the cluster as a whole, or to get access to 
sources of development funding or institutional information on who should take action for concrete sustainable development initiatives.

And finally, there were also demographic questions concerning basic information about the human resource profile of the company interviewed.

\subsection{In-depth interviews and participatory research}

The field research was based on multiple sources of information, from several stakeholders, individual cluster members, local experts, etc. In-depth interviews with cluster participants were also held; they were a crucial element of the field research. An in-depth interview is essentially a communication exercise with a respondent conducted on the basis of a pre-specified mental scenario. Interviews were conducted by persons especially trained for this aim as part of the project, while the interviewer was an active and qualified participant in the communication, in order to gather meaningful strategic and operational information. In-depth interviews are an alternative to focus-group interviews. Due to the specific aim of the project and the diversity of respondents, direct in-depth interviews were chosen. They provide in general a better feeling of ease among interviewees. This is especially important when it comes to issues related to trust evaluation and cooperation between representatives of other companies and institutions within the cluster.

For the sake of comprehensiveness of the research issues, respondents in the cluster were chosen according to following criteria: hierarchal position in the company or institution surveyed, membership of the Aviation Valley Association, and involvement in operations initiated by the Aviation Valley Association. The interviews were carefully prepared in advance, while relevant information about the aim of the project and of the research and about the nature of the questions to be raised during the interview was provided. For representatives of big companies, small and middle-sized companies, and institutions of the business environment who were members of the cluster, similar questions were prepared.

Finally, the aim of the participatory research was to engage representatives of the cluster members in the decision processes and to help in shaping the cluster's development policy. The aim of this action research was to gain knowledge about the future business environment, and strategic knowledge oriented towards the solution of pressing problems. Both aims are interrelated and therefore, it was necessary to engage participants in the organization, as well as in the formulation of strategic conclusions regarding the diagnosis of their collective interests and their connections. The aim of engaging key actors of the cluster in participatory research was also to create awareness of essential issues for these actors, and to show that their voice counts, so that they have a real impact on what is going to happen in the cluster's future. Such research may become a catalyst of proactive involvement, and may create the foundation of establishing participatory mechanisms in the cluster.

\section{Results of a Triple-Layer DEA Benchmark Analysis in the Podkarpackie Region in Poland}

The predominant aim of our research is now to assess the relative economic performance of Polish regions, of counties inside the main region concerned (Podkarpackie), and of individual firms in the Aviation Valley on the basis of an efficiency (or productivity) analysis by means of a DEA (see Figures 3 and 4). In our empirical application we will use the above presented extensive database on Polish regions, counties, and individual actors in the aviation cluster, in combination with the rich performance database for the Podkarpackie region in Poland. We are seeking to achieve a ranking of agents in the triple-layer architecture based on a comprehensive set of indicators and aim to assess the efficiency (or productivity) of the different layers of agents in the context of an effective cluster performance, by examining more carefully the ratio between multi-attribute outputs and multi-attribute inputs of each layer. As mentioned, data envelopment analysis (DEA) is an appropriate tool in this context. Thus, our study aims to provide a critical analysis of the performance data of DMUs in the triple-layer architecture of the Aviation Valley by using an SBM model and a super-efficient (SE) DEA approach, respectively, to position 
Table 4: SBM-SE scores of 16 NUTS-3 Voivodships of Poland

\begin{tabular}{llclll}
\hline Nr. & DMU Voivodship & Score & Nr. & DMU Voivodship & Score \\
\hline 1 & DOLNOŚLASKIE & 0.561 & 9 & PODKARPACKIE & 0.755 \\
2 & KUJAWSKO-POMORSKIE & 0.636 & 10 & PODLASKIE & 0.995 \\
3 & LÓDZKIE & 0.592 & 11 & POMORSKIE & 0.443 \\
4 & LUBELSKIE & 0.626 & 12 & ŚLA_SKIE & 0.477 \\
5 & LUBUSKIE & 1.730 & 13 & SWIETOKRZYSKIE & 0.469 \\
6 & MAŁOPOLSKIE & 0.388 & 14 & WARMIŃSKO-MAZURSKIE & 0.849 \\
7 & MAZOWIECKIE & 19.195 & 15 & WIELKOPOLSKIE & 0.768 \\
8 & OPOLSKIE & 0.385 & 16 & ZACHODNIOPOMORSKIE & 0.582 \\
\hline
\end{tabular}

Source: Authors' own calculation

Table 5: SBM-SE scores of 25 NUTS-4 Powiats of Podkarpackie in Poland

\begin{tabular}{llllll}
\hline Nr. & DMU Powiat & Score & Nr. & DMU Powiat & Score \\
\hline 1 & bieszczadzki & 1.390 & 13 & m.Przemysl & 1.003 \\
2 & brzozowski & 0.687 & 14 & m.Rzeszow & 0.642 \\
3 & debicki & 0.908 & 15 & m.Tarnobrzeg & 0.727 \\
4 & jaroslawski & 1.012 & 16 & mielecki & 0.708 \\
5 & jasielski & 0.693 & 17 & nizanski & 1.082 \\
6 & kolbuszowski & 1.062 & 18 & przemyski & 0.628 \\
7 & kroSnieNski & 0.711 & 19 & przeworski & 0.757 \\
8 & lancucki & 0.679 & 20 & ropczycko-sedziszowski & 0.628 \\
9 & leski & 0.637 & 21 & rzeszowski & 0.649 \\
10 & lezajski & 0.404 & 22 & sanocki & 1.038 \\
11 & lubaczowski & 0.788 & 23 & stalowowolski & 1.039 \\
12 & m.Krosno & 1.011 & 24 & strzyzowski & 0.811 \\
& & & 25 & tarnobrzeski & 0.434 \\
\hline
\end{tabular}

Source: Authors' own calculation

these DMUs unambiguously on the basis of their relative performance. The empirical results of the SBM-SE model based on the triple-layer approach will now be presented in Tables 4-6 for each of the three layers concerned.

We will offer here a concise interpretation of the findings in these tables. As far as Table 1 is concerned, it turns out that there are only 2 super-efficient voivodships on the NUTS-3 level in Poland, with a clearly prominent position for Mazowieckie, situated in the central-eastern part of Poland. There is quite some variation among the efficiency outcomes of the non-efficient voivodships in Poland. It is noteworthy that the efficiency of the Podkarpackie region - which is the region addressed in our study - does not differ significantly from the Wielkopolskie region which is a rather strong region in the Western part of Poland dominated by Poznan. Thus, the Podkarpackie region is performing rather well, despite its peripheral location. This may be seen as a promising sign for future development efforts.

On the next layer of powiats (NUTS-4 regions or counties) within the Podkarpackie region, we observe quite a few (8) super-efficient areas. They are scattered all over the Podkarpackie voivodship, which means that the efficiency performance of these counties offers a balanced geographical picture, except for these powiats that are external border regions (e.g., to Ukraine). This finding is interesting, as the aviation industry in the Podkarpackie region is not concentrated in one point location, but shows a broadly dispersed cluster pattern all over this region. Apparently, the benefits of this strategy accrue to a wide group of counties in the voivodship. The relatively low score of Rzeszow has to do with the fact that the city itself does not have a strong industrial base, since most aviation activities are located in a wide radius around the city. 
Table 6: SBM-SE scores of 55 firms in the Aviation Cluster in Podkarpackie in Poland

\begin{tabular}{llllll}
\hline Nr. & DMU Firms & Score & Nr. & DMU Firms & Score \\
\hline 1 & AD10 & 1.016 & 28 & MA39 & 0.710 \\
2 & Ae11 & 1.007 & 29 & MC27 & 0.731 \\
3 & Ae35 & 0.829 & 30 & Me14 & 1.000 \\
4 & Ai20 & 0.844 & 31 & MI52 & 0.316 \\
5 & AR4 & 1.000 & 32 & MT30 & 0.744 \\
6 & AS48 & 0.502 & 33 & No50 & 0.475 \\
7 & AT40 & 0.559 & 34 & Po15 & 0.960 \\
8 & BE42 & 0.601 & 35 & Pol43 & 0.691 \\
9 & BM8 & 1.049 & 36 & PZ19 & 0.927 \\
10 & Bo21 & 0.916 & 37 & PZ45 & 0.646 \\
11 & BR17 & 0.793 & 38 & Re16 & 0.967 \\
12 & CA13 & 1.001 & 39 & Ro47 & 0.640 \\
13 & CO38 & 0.476 & 40 & SE7 & 1.032 \\
14 & EL48 & 0.493 & 41 & Sp28 & 0.775 \\
15 & Eu32 & 0.857 & 42 & Th18 & 0.862 \\
16 & Fi3 & 1.053 & 44 & Tr12 & 1.008 \\
17 & FL33 & 0.857 & 45 & Un29 & 0.498 \\
18 & Fo36 & 0.347 & 46 & UT9 & 0.830 \\
19 & GU5 & 1.088 & 47 & Wa31 & 1.022 \\
20 & HA53 & 0.396 & 48 & Wi26 & 0.800 \\
21 & He2 & 1.529 & 49 & WS25 & 0.6813 \\
22 & Hi34 & 0.767 & 50 & WS46 & 0.540 \\
23 & In24 & 0.805 & 51 & Wy49 & 0.545 \\
24 & IW23 & 0.816 & 52 & Ze41 & 0.714 \\
25 & KA1 & 1.000 & 53 & ZM44 & 0.581 \\
26 & Ma22 & 0.887 & 54 & ZP6 & 1.040 \\
27 & Ma37 & 0.456 & & & \\
\hline
\end{tabular}

Source: Authors' own calculation

Finally, the efficiency scores for the firms in the aviation industry shows an interesting pattern. There is apparently a set of 16 super-efficient firms, and a broad distribution of less efficient firms. As mentioned, details on these anonymized firms cannot be provided, but there is also a fair balance between small and large firms. It is also interesting to observe that there are a limited number of very inefficient firms with rather low scores. Consequently, for specific enterprises in this aviation cluster there is much scope for improving their business performance. It is also noteworthy that the geographic distribution of efficient and inefficient firms over the various powiats is rather balanced.

The overall conclusion from our triple-layer DEA model application is that on all levels of decision-making - ranging from individual business firms in the aviation cluster through counties (which provide the direct geographical location area for these firms) to the level of voivodships charged with official regional policy competences - there is still much scope for socio-economic performance improvement. The Podkarpackie region has in the past decade demonstrated a great potential in enhancing its competitive position as an effective aviation cluster (see Kaszuba 2012), but there is undoubtedly more room for strengthening its position.

It should be added that in a deterministic DEA model these findings are of course numerically correct, but that in policy practice such accurate and ambitious adjustments by DMUs may sometimes be hard to achieve. Nevertheless, this information is indicative for the direction and intensity of necessary policy handled in a region, powiat, and firm so as to become more efficient in a competitive environment. In conclusion, there is a need for an intensified policy effort to achieve and strengthen the socio-economic vitality and efficiency of the aviation actors in the triple-layer architecture in Poland. 


\section{Policy Lessons}

Regional development policy aims to cope with the challenge of spatial disparities. It is based on a smart combination of various critical capital assets in a region which functionally and spatially interact and which yield synergetic economic opportunities and promising challenges for innovation and progress. The present study regards sustainable territorial performance - as a manifestation of regional development - as the overarching principle for competitive advantages and economic growth in a system of regions, which is particularly induced by territorial capital, comprising human capital, infrastructural capital, and social capital. In the long-standing tradition of regional development policy, a wide variety of effective facilitators or drivers of accelerated spatial growth has been distinguished, for instance, industrial districts, growth poles, growth centers, industrial complexes, special economic zones, communication axes, and so forth.

Regional development calls for an active involvement of stakeholders or agents (DMUs) at different institutional levels. Awareness of the actual position of a DMU on the achievement ladder is a sine qua non for performance improvement. The Aviation Valley cluster in the Podkarpackie region in South-East Poland offers a good example of a dedicated but complex regional development effort; it is not only a fascinating and pioneering cluster policy experiment, but offers also a great opportunity for designing and implementing innovative and effective cluster research initiatives and for building strong business networks and creating 'collective buying power'. It is indeed a miraculous and encouraging phenomenon that a less privileged and peripheral territory like the Podkarpackie region is able to act as a seedbed for a broad portfolio of advanced aviation activities, not only with a great economic spinoff for the area concerned, but also with significant spillovers to the rest of the country and of Europe, and in various cases even with a world-wide outreach.

The Podkarpackie voivodship and its powiats are confronted with a great many challenges, notably geographic isolation, far-reaching demographic transformations, complex force fields in this part of Europe, unequal social participation, and ever-rising mobility trends. These multi-faceted challenges may be turned into new opportunities, in particular in such concerns as advanced business and environmental facilities, knowledge-intensive and creative strategies for socioeconomic well-being and prosperity (see Kourtit, Nijkamp 2013b) with a strong need for intensified policy efforts, and availability of a strong and dedicated workforce in high-tech engineering.

The general challenge is to improve the competitive high performance of the Podkarpackie region, to strengthen and stimulate its constituent powiats, and to improve further the attractiveness of the Aviation Valley as a sustainable high-quality place to work and live, and to incorporate technology and innovation in overall sustainable developmental strategies so as to make the Valley a seedbed for global frontrunners for future development. The notion of a territorial performance index (TPI) has proven its relevance and applicability in our research.

In this context, strong and fit-for-purpose territorial capital may create a strong Aviation Valley, in particular, through strengthening information and knowledge facilities, advancing institutional support systems, fostering fruitful business networking initiatives, recruiting new talents on the labor market, favoring high-skilled job opportunities and establishing a sufficient and effective venture capital system (see Kourtit, Nijkamp 2013b, Kourtit 2015). All such effective cluster conditions are critical success factors for a promising living, working, and business environment in the Aviation Valley. A mixture of advanced process, product and service innovation initiatives, advanced labor force concentrations, socio-cultural initiatives, interconnected public facilities, and geographic knowledge synergy may be regarded as the constituents of a successful regional creative and innovation system that forms the basis for an effective aviation cluster.

In our applied empirical case study on the Aviation Valley in the Podkarpackie region in Poland, we have focused our attention in particular on the quality of human capital, social characteristics, and on infrastructural amenities synergy from the perspective of an effective cluster against the background of social and economic dynamics at different scale levels, on the basis of the TPI model. Clearly, the aim of our analysis was not to 
offer a critical review of current official development policies and implementations in the region concerned. We have rather addressed the information base and the conceptual framing of the strong and weak points in this area, with a particular view to regional, local, and industrial detail.

At the level of Polish voivodships, the regions Mazowieckie and Lubuskie are found to be efficient (with efficiency scores equal to 1) based on our DEA model. This "efficiency" means that these two regions can produce a large amount of economic performance (outputs), with the use of relatively small amount of inputs (territorial capital). This result may be confronted with relatively highly inefficient regions, such as Małopolskie, Świętokrzyskie and Opolskie. The Podkarpackie region is found in a middle position with a trend to improve its performance.

At the next spatial scale, viz. of powiats, the most efficient powiats in the Podkarpackie region in Poland are Bieszczadzki, Sanocki, Leski, Lubaczowski, Przemyski, Kolbuszowski, Strzyzowski and Tarnobrzeski. These powiats appear to offer new opportunities for social and economic synergy as a result of a strong county attractiveness and the presence of broadly based public and private facilities. There is obviously also a great opportunity for advanced growth initiatives and improvement strategies of lower performing powiats. Apparently, territorial capital is very supportive for high aviation industry performance.

Finally, by looking at the third stage for efficient firms in the Aviation Valley in the Podkarpackie region in Poland, we can by means of our DEA model identify the firms with a maximum level of efficiency, which from our analysis turns out to comprise 16 firms. These firms may be labelled the 'high performing firms' among our sample of 55 high-tech firms in the Aviation Valley. These 'high performing firms' are able to exploit their high socio-economic and technological performance even more, as they have strongly established business resources that underscore the importance of territorial capital.

In conclusion, a strategic view on a high performing region, country, or firm may be used as an effective approach to identify important and smart KPIs (key performance indicators) that are involved to maximize the creative, innovative, and technological potential of the agent concerned. The triple-layer design of our research, addressing three types of actors with distinct competences, has proven to be a valuable methodological departure for an effective cluster analysis of the Aviation Valley in Poland. This approach may provide untapped opportunities for knowledge-based institutional, geographicallyfocused, and cultural and business activities, that are needed in order to stay ahead of the fierce competition and to advance continuously the high socio-economic achievement potential.

Clearly, any DEA study - including ours - is a comparative benchmarking analysis of the efficiency - or the broad economic performance - of various stakeholders or actors (e.g., regions, agencies, firms). The reasons why some actors have an exceptional performance in comparison to others in the same sample call for further specific case research. The same holds for all other DMUs who want to improve their performance position on the achievement ladder. It should be added that a sensitivity analysis using another DEA method, viz. the CCR model, leads to largely the same result, so that our findings seem to be rather robust and consistent. It should be added that essentially a wide array of DEA variants could have been applied (such as BCC, Malmquist indices, etc.), but that would have led to a different study. For more details on this option we refer to a recent study by Susuki, Nijkamp (2017).

The overall conclusion is that the Aviation Valley in the Podkarpackie region in Poland has unique opportunities and a rich scope for further improvement and development and may act as a catalyst for welfare improvement in this territory. 


\section{References}

Acz Z, Braunerhjelm P, Audretsch D, Carlsson B (2009) The knowledge spill-over theory of entrepreneurship. Small Business Economics 32: 15-30. CrossRef.

Adler N, Golany B (2001) Evaluation of deregulated airline networks using data envelopment analysis combined with principal component analysis with an application to Western Europe. European Journal of Operational Research 132[2]: 260-273. CrossRef.

Andersson M, Klaesson J, Larsson JP (2016) How local are spatial density externalities? Neighbourhood effects in agglomeration economies. Regional Studies 50[6]: 1082-1095. CrossRef.

Arribas-Bel D, Kourtit K, Nijkamp P (2013) Benchmarking of world cities through self-organizing maps. Cities 31: 248-257. CrossRef.

Aschauer DA (1989) Is public expenditure productive? Journal of Monetary Economics 23: 177-200. CrossRef.

Asheim B, Cooke P, Martin R (2006) Clusters and Regional Development: Critical Reflections and Explorations. Routledge, London

Baczko T (2011) Report on innovativeness of the aviation sector in Poland in 2010. http://issuu.com/inepan/docs/ang_pdf_raport_okladki

Batabyal A, Nijkamp P (2015) The Region and Trade: New Analytical Directions. World Scientific Publishing, New York

Becker GS (2009) Human Capital. University of Chicago Press, Chicago. CrossRef.

Berechman J, de Wit JG (1996) An analysis of the effects of European aviation deregulation on an airline's network structure and choice of a primary West-European hub airport. Journal of Transport Economics and Policy 30[3]: 251-274

Bochniarz Z (2007) Strategic issues of financing sustainable development in transforming economies: The case of Central Europe. In: Xiaowen J, Ebben J (eds), Entrepreneurial Strategy Innovation and Sustainable Development. Sichuan University Press, Chengdu, China, 1029-1049

Bourdieu P (1981) Décrire et préscrire. note sur les conditions de possibilité et limites de l'efficacité. Actes de la Recherche en Sciences Sociales 38[1]: 69-73. CrossRef.

Bröcker J, Rietveld P (2009) Infrastructure and regional development. In: Capello R, Nijkamp P (eds), Handbook of Regional Growth and Development Theories. Edward Elgar, Cheltenham, 152-281. CrossRef.

Burghouwt G, Huys M (2003) Deregulation and the consequences for airport planning in Europe. disP-The Planning Review 39[154]: 37-45. CrossRef.

Button K (2002) Debunking some common myths about airport hubs. Journal of Air Transport Management 8[3]: 177-188. CrossRef.

CAI - Community Attributes Inc. (2013) Washington State Aerospace Industry. Community Attributes Inc. (CAI), Seattle, Washington

Calzonetti FJ, Reid N (2013) The role diversities in supporting new technology industries through commercialisation spin-off activities. Studies in Regional Science 43[1]: 7-23. CrossRef.

Camagni R (2002) On the concept of territorial competitiveness: sound or misleading? paper presented at the ERSA conference 2002, European Regional Science Association, http://www-sre.wu.ac.at/ersa/ersaconfs/ersa02/cd-rom/papers/518.pdf 
Camagni R (2009) Territorial capital and regional development. In: Capello R, Nijkamp P (eds), Handbook of Regional Growth and Development Theories. Edward Elgar, Cheltenham, 118-132. CrossRef.

Camagni R, Capello R (2011) Spatial Scenarios in a Global Perspective: Europe and the Latin Arc Countries. Edward Elgar, Cheltenham. CrossRef.

Camagni R, Capello R (2013) Regional competitiveness and territorial capital: A conceptual approach and empirical evidence from the European Union. Regional Studies 47[9]: 1383-1402. CrossRef.

Camagni R, Capello R (2015) Rationale and design of EU cohesion policies in a period of crisis. Regional Science Policy and Practice 7[1]: 25-49. CrossRef.

Capello R, Caragliu A, Nijkamp P (2011) Territorial capital and regional growth: Increasing returns in knowledge use. Tijdschrift voor Economische en Sociale Geographie 102[4]: 385-405. CrossRef.

Capello R, Nijkamp P (2009) Handbook of Regional Growth and Development Theories. Edward Elgar, Cheltenham. CrossRef.

Caragliu A (2015) The economics of proximity. PhD dissertation, VU University, Amsterdam

Celbis G, Nijkamp P, Poot J (2015) Infrastructure and trade: A meta-analysis. REGION 1[1]: 25-64. CrossRef.

Charnes A, Cooper WW, Lewin AY, Seiford LM (1994) Data Envelopment Analysis: Theory, Methodology and Applications. Kluwer, Boston. CrossRef.

Charnes A, Cooper WW, Rhodes E (1978) Measuring the efficiency of decision making units. European Journal of Operational Research 2: 429-444. CrossRef.

Coleman JS (1988) Social capital in the creation of human capital. The American Journal of Sociology 94: 95-120. CrossRef.

Cooper WW, Seiford L, Zhu J (2006) Handbook of Data Envelopment Analysis. Kluwer, Boston. CrossRef.

De la Fuente A, Vives X (1995) Infrastructure and education as instruments of regional policy. Economic Policy 20: 11-54

ECORYS (2009) Competitiveness of the EU aerospace industry. Rotterdam

Elburz Z, Nijkamp P, Pels E (2015) Public meta-analysis. Discussion paper, Department of Spatial Economics, VU University, Amsterdam

European Aeronautics (2001) Meeting society's needs and winning global leadership. Report of the group of personalities, http://www.acare4europe.org/sites/acare4europe.org/files/document/Vision\%202020_0.pdfm

European Commission (2005) Territorial state and perspectives of the European Union. Scoping document and summary of political messages, Brussels, Belgium

Fratesi U, Perucca G (2014) Territorial capital and the effectiveness of cohesion policies: An assessment for CEE regions. Investigaciones Regionales 29: 164-191

Färe R, Grosskopf S, Russell R (1998) Index Numbers. Kluwer, Boston

Fukuyama F (2001) Social capital, civil society and development. Third World Quarterly 22[1]: 7-20. CrossRef.

Gibson MD, Kundu S, Satish M (2013) Dispersion model evaluation of PM2.5, NOx and SO2 from point and major line sources in Nova Scotia, Canada using AERMOD Gaussian plume air dispersion model. Atmospheric Pollution Research 4: 157-167. CrossRef. 
Hanifan LJC (1916) The rural school community centre. Annals of the American Academy of Political and Social 67[1]: 130-138. CrossRef.

Healy P, Cote S (2001) The wellbeing of nations: The role of human and social capital, education and skills. Oecd, paris

Heckman JJ (2000) Policies to foster human capital. 54[1]: 3-56. CrossRef.

Jacobs J (1961) The Death and Life of Great American Cities. Random House, New York. CrossRef.

Kaasa A, Part A (2008) Human capital and social capital as interacting factors of economic development: Evidence from Europe. IAREG, Estonia, working paper IAREG WP 2/04. CrossRef.

Kasabov E, Sundaram U (2016) Conceptualizing clusters as dynamic and path-dependent pools of skills. Regional Studies 50[9]: 1520-1536. CrossRef.

Kaszuba K (2012) Aviation cluster 'aviation valley' - case study. Report, Rzeszow School of Business, Rzeszow, Poland

Kourtit K (2014) Competiveness in urban systems - studies on the 'urban century'. VU University, Amsterdam, The Netherlands

Kourtit K (2015) The 'new urban world' - economic-geographical studies on the performance of urban systems. Adam Mickiewicz University, Poznan, Poland

Kourtit K, Nijkamp P (2013a) In search of creative champions in high-tech spaces: A spatial application of strategic performance management. Journal of Regional Science 53[5]: 749-777. CrossRef.

Kourtit K, Nijkamp P (2013b) The new urban world - The challenge of cities in decline. Romanian Journal of Regional Science 7[2]: 9-28

Kourtit K, Nijkamp P (2017) A multi-layer analysis of effective clusters in regional development policy: A case study on Poland. Public administration and regional studies (forthcoming)

Kourtit K, Nijkamp. P, Suzuki S (2013) Exceptional places: The rat race between world cities. Computers, Environment and Urban Systems 38: 67-77

Nijkamp P (1996) Liberalization of air transport in Europe: The survival of the fittest? Swiss Journal of Economics and Statistics 132[3]: 257-278

Nijkamp P (2008) XXQ factors for sustainable urban development: A systems economics view. Romanian Journal of Regional Science 2[1]: 1-34

Nijkamp P (2016) The resourceful regions: A new conceptualisation of regional development strategies. Journal of Regional Research 36: 191-214

OECD (2001) OECD territorial outlook. OECD, Paris

Perucca G (2014) The role of territorial capital in local economic growth: Evidence from Italy. European Planning Studies 22[3]: 537-562. CrossRef.

Porter ME (1990) The Competitive Advantage of Nations. MacMillan, London. CrossRef.

Putnam R (1993) The prosperous community. The American Prospect 13[4]: 35-42

Ratajczak W (2008) Impact of Poland's integration with the European Union on the socio-economic status of Polish regions. Moravian Geographical Reports 16[1]: 2-15

Ravikumar B, Glomm G (1992) Public versus private investment in human capital. Journal of Political Economy 100[4]: 818-834. CrossRef. 
Ray SC (2004) Data Envelopment Analysis: Theory and Techniques for Economics and Operations Research. Cambridge University Press, Cambridge

Rodriguez-Pose A, Fratesi U (2004) Between development and social policies. Regional Studies 38: 97-113

Schönfeld T, Jouaillec F (2008) The regional aerospace cluster policy in Europe. Paper presented to the 26th International Congress of the Aeronautical Sciences. http://www.icas.org/ICAS_ARCHIVE/ICAS2008/PAPERS/628.PDF

Scholl T, Brenner T (2016) Detecting spatial clustering using a firm-level cluster index. Regional Studies 50[6]: 1054-1068. CrossRef.

Schultz Th (1961) Investment in human capital. American Economic Review 51[1]: 1-17

Sommers P, Beyers WB, Wenzel A (2008) Industry cluster analysis for Washington State, workforce development areas. Washington State Workforce Board, Seattle, Washington

Statistical Office in Rzeszow (2014) Podkarpackie voivodship - subregions, powiats, gminas, podkarpackie voivodship. http://rzeszow.stat.gov.pl/publikacje-i-foldery/rocznikistatystyczne/wojewodztwo-podkarpackie-podregiony-powiaty-gminy-2014,4,11.html

Susuki S, Nijkamp P (2017) An evaluation of energy-environment-economic efficiency for Asian countries: A proposal for a time-series target-oriented DFM model in data envelopment analysis. In: Batabyal A, Nijkamp P (eds), Regional Growth and Sustainable Development in Asia. Springer, Singapore (forthcoming). CrossRef.

Suzuki S, Nijkamp P (2016a) An evaluation of energy-environment-economic efficiency for EU, APEC and ASEAN countries: Design of a target-oriented DFM model with fixed factors in data envelopment analysis. Energy Policy 88: 100-112. CrossRef.

Suzuki S, Nijkamp P (2016b) Preference elicitation in generalized data envelopment analysis: In search of a new energy balance in Japan. In: Shibusawa H, Sakurai K, Mizunoya T, Uchida S (eds), Socioeconomic Environmental Policies and Evaluations in Regional Science. Springer, Singapore, 601-618. CrossRef.

Suzuki S, Nijkamp P, Rietveld P (2015) A target-oriented data envelopment analysis for energy-environment efficiency improvement in Japan. Energy Efficiency 8[3]: 433-446. CrossRef.

Suzuki S, Nijkamp P, Rietveld P, Pels E (2010) A distance friction minimization approach in data envelopment analysis: A comparative study on airport efficiency. European Journal of Operational Research 207: 1104-1115. CrossRef.

Tone K (2001) A slacks-based measure of efficiency in data envelopment analysis. European Journal of Operational Research 130: 498-509. CrossRef.

Westlund H (2006) Social Capital in the Knowledge Economy: Theory and Empirics. Springer, Berlin, Heidelberg

Zhu J (2003) Quantitative Models for Performance Evaluation and Benchmarking. Springer, Berlin. CrossRef.

Zhu J, Cook W (2007) Modeling data irregularities and structural complexities in data envelopment analysis. Springer, New York

Zuliani JM, Jalebert G (2005) L' Industrie Aeronautique Européenne. L' Espace Geographique 34[2]: 117-144 